\title{
Profil Retinopathy Hipertensi di Rumah Sakit DR. M Djamil Padang
}

Khalilul Rahman, Rahmi Yolla Yusticia

\begin{abstract}
Abstrak
Pendahuluan:Retinopati hipertensi adalah kondisi yang ditandai perubahan dengan vascular pada pasien dengan peningkatan tekanan darah. Perubahan vaskular retina pada hipertensi secara umum dapat diklasifikasikan menjadi perubahan arteriolar dan lesi retinopati yang lebih lanjut. Tujuan:Untuk mengetahui profil retinopati hipertensi di RSUP Dr. M. Djamil Padang. Metode:Semua pasien hipertensi dari Bagian IImu Penyakit Dalam yang berobat kepoli mata sejak Juli - September 2012. Hasil: Dari 86 pasien, 38 orang (44,19\%) didiagnosa sebagai Retinopati Hipertensi Keith Wagenergrade II, 23,6\% grade I, 18,61\% tidak ada tanda Retinopati Hipertensi, dan tidak ada yang didiagnosis dengan grade IV. Berdasarkan kelompok umur,didapat 40 pasien laki-laki dan 46 perempuan dengan frekwensi terbanyak pada 51-60 tahun 34 orang, terutama pada Grade II sebanyak 19 orang. Berdasarkan riwayat hipertensi terbanyak pada kelompok umur 5-10 tahun adalah 20 orang. Hanya 49 kaus (56,98\%) yang terkontrol dengan obat. Jika berdasarkan penyakit sistemik lainnya, terbanyak dengan diabetes melitus $33,72 \%$. Berdasarkan faktor resiko yang didapat dislipidemia merupakan faktor resiko terbanyak yaitu 50 orang (44,64\%). Diikuti 33 orang (29,46\%) perokok. Distribusi BMI didapatkan normal pada38 orang (44,19\%). Pasien yang tidak melakukan olahraga sebanyak 60 orang (69,76\%). Kesimpulan:Retinopati hipertensi KW II adalah kasus yang paling banyak ditemukan dengan riwayat hipertensi selama 5-10 tahun. Faktor risiko utamaadalahdislipidemiadanumur rata-rata yaitu 51-60 tahun.
\end{abstract}

Kata kunci: Hipertensi, retinopati hipertensi, klasifikasi Keith-Wagener

\section{Abstract}

Purpose: Hypertensive retinopathy is condition characterized by a spectrum of retinal vascular signs in people with elevated blood pressure. Hypertensive retinal vascular signs can be broadly classified into arteriolar changes and more advanced retinopathy lesions. Objective : To describe hypertensive retinopathy profile at Dr. M. Djamil Hospital PadangMethods: All of patient known as hypertension from Internal Departement were looked for hypertensive retinopathy at out patient clinic of ophthalmology departement in July-September 2012. Result : Of the 86 patients, 38 cases (44,18\%) had hypertensive retinopathy Keith-Wagener grade II, 23,6\% had grade I, 18,6\% had no sign hypertensive retinopathy, and had no grade IV. A total of 86 patients (40 male, 46 female) with age group was 51-60 yo for 34 cases. The average historical of hypertension for 5-10 years is 20 cases. Only 49 cases (56,98\%) had hipertensive controlled by drugs. Another most common sistemic disease history is diabetes mellitus $33,72 \%$ while the most common risk factor is dyslipidemia 50(44,64\%) follow by smoking 33(29,46\%). The BMl in average patient is normal 38(44,19\%). Commonly, the patients didn't do exercise 60 (69,76\%). Conclusion : Hypertensive retinopathy $K W \quad$ II is the most cases found with the historical hypertension for 5-10 years. The most common risk factor is dyslipidemia and the average age is 51-60 yo.

Keywords:Hypertension, hypertensive retinopathy, Keith-Wagener classification.

Affiliasi penulis : Bagian mata, Fakultas Kedokteran Universitas Andalas

Korespondensi : Khalilul Rahmanluly947@hotmail.com

\section{PENDAHULUAN}

Hipertensi merupakan faktor resiko mortalitas keempat terbesar di dunia dengan angka sekitar $6 \%$ dari seluruh kematian. Diperkirakan 58 juta dewasa di Amerika Serikat menderita hipertensi dengan peningkatan tekanan darah (sistolik $\geq 140 \mathrm{mmHg}$ atau diastolik $\geq 90 \mathrm{mmHg}$ ) atau yang mendapat obat antihipertensi. ${ }^{1,2}$

Peningkatan tekanan darah ini menyebabkan sirkulasi retina mengalami perubahan secara patofisiologi, spektrum tanda klinis inilah yang dikenal sebagai retinopati hipertensi. Retinopati hipertensi merupakan salah satu dari beberapa tanda terdapatnya kerusakan organ target pada hipertensi. Berdasarkan kriteria Joint National Committee on Prevention, Detection, Evaluation, and Treatment of High Blood Pressure (JNC), terdapatnya retinopati merupakan suatu indikasi untuk memulai terapi antihipertensif, meskipun pada orang dengan hipertensi stadium 1 (tekanan darah 140-159/90-99 $\mathrm{mm} \mathrm{Hg}$ ) tanpa adanya kerusakan organ target yang lain. 3,4

Retinopati hipertensi pertama kali dideskripsikan oleh Robert Marcus Gunn, yang pada tahun 1898 mempresentasikan hasil pengamatan yang dilakukannya terhadap pembuluh darah retina 
pada pasien-pasien dengan penyakit ginjal dan hipertensi. Tanda-tanda pada retina yang diamatinya berupa penyempitan arteriol fokal dan menyeluruh, penekanan arteriolvenosa, perdarahan flame-shaped, cotton-wool spots dan edem papil. Terdapatnya tandatanda retinopati tersebut berhubungan dengan peningkatan resiko dari penyakit jantung koroner dan stroke sehingga deteksi dini dari retinopati hipertensi memegang peranan yang penting dalam manajemen pasien-pasien dengan hipertensi. ${ }^{4,5}$

Pada penelitian Erden $\mathrm{S}$ dan Bicakci $\mathrm{E}$ tahun 2011 di Turki, didapatkan retinopati hipertensi pada usia lebih dari 40 tahun dengan proporsi terbanyak $66,3 \%$ pada stadium I dan II menurut Keith Wagener. Penelitian ini juga mendapatkan adanya hubungan peningkatan tekanan darah dengan penyempitan arteriolar retina difus dan arteriovenous nicking pada pasien dengan peningkatan tekanan darah 6-8 tahun sebelum pemeriksaan. Prevalensi retinopati hipertensi didapatkan 2-15\% dari berbagai penelitian di dunia. ${ }^{6}$

Penelitian ini dilakukan untuk mengetahui profil pasien hipertensi yang datang berobat ke poli mata sub bagian vitreo retina pada bulan Juli-September 2012 yang sudah di diagnosis hipertensi oleh bagian penyakit dalam. Hasil penelitian ini diharapkan dapat bermanfaat untuk data dasar dan follow up progresifitas dari pasien yang diperiksa untuk beberapa tahun ke depan.

\section{RETINOPATI HIPERTENSI}

Retinopati hipertensi adalah suatu keadaan yang ditandai oleh suatu kumpulan tanda-tanda perubahan vaskular retina yang secara patologis berhubungan dengan kerusakan mikro vascular sebagai akibat tekanan darah yang meningkat. Retinopati hipertensilebihseringterjadipada orang denganusia 40 tahun atau lebih dan lebih banyak dijumpai pada orang berkulit hitam dibandingkan orang berkulit putih. , $^{3,4}$

Patofisiologi dari retinopatihi pertensi diawali penyempitan arteriol yang dimediasi auto regulasi. Hipertensi yang berlangsung kronis akan menyebabkan proses arteriole sklerosis dan dapat terjadi oklusi arteriol. Apabila terjadi peningkatan tekanan darah yang kontinu dan ekstrem, hal ini dapat menimbulkan kegagalan mekanisme auto regulasi vaskular retina, yang memicu gangguan pada sel endotel dan kerusakan sawar darah retina, yang menyebabkan iskemia retina dan kebocoran cairan, darah, dan makro molekul ke dalam retina. ${ }^{7,8,9}$

Lesi yang terdapat pada retinopati hipertensi terdiri dari lesi vaskular dan ekstravaskular, meskipun pada beberapa lesi ekstravaskular faktor utamanya adalah kelainan vaskular retina. Lesi vaskular retina meliputi perubahan arteriol retina, focal intraretinal periarteriolar transudates (FIPTs), iskemia retina bagian dalam (cotton-wool spots), perubahan kapiler dan vena retina serta peningkatan permeabilitas jaringan kapiler retina. Lesi ekstravaskular retina meliputi perdarahan retina, edema makula dan retina, deposit lipid retina (hard exudates), kehilangan serabut saraf retina dan edem papil. ${ }^{3,10}$

\section{A. Penyempitan Arteriolar}

Penyempitan arteriol difus merupakan tanda retinopati hipertensi. Meskipun dapat juga terlihat sebagai respon vasospastik akut dari hipertensi akut, tapi lebih sering terlihat pada hipertensi kronik. Pengurangan kaliber arteriol ini akan mengurangi rasio arteri : vena yang berhubungan dengan hipertensi. Rasio normalnya adalah $2: 3 .^{1,9,10}$

Penyempitan arteriol fokal berkaitan pada area yang terlokalisir dengan spasme dinding arteriol dan dapat bersifat reversibel. Penyempitan arteriol fokal yang persisten dapat menimbulkan edem pada dinding arteriol atau fibrosis pada area yang terlokalisir. ${ }^{1,12}$

\section{B. Arteriosklerosis dan Atherosklerosis}

Arteriosklerosis hipertensif berhubungan dengan peningkatan progresif pada komponen muskular dan elastis dari dinding arteriol yang dipicu oleh hipertensi. Pada hipertensi yang sudah lama, jaringan elastis membentuk lapisan konsentrik multipel dalam intima arteriol. Lapisan muskular diganti oleh jaringan kolagen, dan intima dapat diganti dengan penebalan hialin. Perubahan ini menghasilkan gambaran onion skin yang dikemukakan oleh Ashton dan Harry. ${ }^{1,12,13}$ 
Atherosklerosis berhubungan dengan perubahan yang berkembang pada intima vena lebih besar, arteri yang medium dan besar. Deposit lemak pada intima sering berhubungan dengan kalsifikasi dan fibrosis, yang dapat timbul dalam lumen dan memicu trombosis arteri. Perubahan atherosklerosis dapat terlihat pada arteri retina perifer dan pada arteri choroidal dan siliaris. $1,7,10$

\section{Perubahan Sklerotik}

Peningkatan penebalan dinding arteriol disebabkan oleh proses arteriosklerotik menyebabkan perubahan progresif dalam gambaran reflek cahaya dari arteriol. Pada dinding yang menebal, reflek cahaya berkurang kecerahannya dan menjadi agak lebih luas, kusam dan lebih difus. Ini adalah tanda awal arteriolsklerosis. ${ }^{1,9,10}$

Adanya peningkatan penebalan dinding arteriol dan pengecilan lumen, lebih lanjut menyebabkan reflek cahaya seperti coklat kemerahan yang disebut reflek copper wire. Pada proses yang terus berlanjut akan menberikan gambaran suatu silver wire, ketika kolom darah tidak bisa lagi divisualisasikan. ${ }^{1,12}$

Penebalan arteriol sklerotik pada dinding vena juga berefek pada gambaran arteriol venous crossing. Sklerosis vaskular dan dan proliferasi sel glial perivaskuler berkontribusi pada penekanan/ kompresi arteriolvenous nicking. Penekanan vena (Gunn's sign) ini bervariasi tingkatannya. Perubahan sklerotik dapat juga menyebabkan defleksi vena saat persilangan dengan arteri (Salus sign). ${ }^{1,10,11}$ Mikroaneurisma retina dapat terjadi pada variasi yang luas dari penyakit vaskular retina, termasuk hipertensi dan temuan non spesifik lainnya. Menurut Ashton, adanya hubungan mikroaneurisma, cottonwool spot, dan nonperfusi dari kapiler retina dalam hipertensi. ${ }^{1,9,12}$

Pada kasus hipertensi akut dapat masuk pada tahap maligna atau dipercepat, dengan tanda adanya nekrosis fibrinoid arteriol dengan edem papil. Penyebab utama dari edem papil ini adalah adanya gangguan dari sirkulasi arteriol, sehingga menyebabkan terjadinya iskemik. Nekrosis fibrinoid lebih sering melibatkan arteri choroidal daripada arteri retina. Dengan terganggunya inner blood retinal barrier akan mengakibatkan terjadinya edem retina. ${ }^{1,10,14}$

\section{Diagnosis dan Pemeriksaan Penunjang}

Diagnosis retinopati hipertensi dibuat secara klinis dengan ditemukannya karekteristik fundus pada pemeriksaan ophthalmoscopy pada pasien dengan hipertensi arterial sistemik. Foto fundus merupakan cara yang sangat bermanfaat untuk dokumen dan monitor progresifitas dari retinopati hipertensi ini. Fluorescein angiography (FFA) dapat digunakan, tapi bukan krusial untuk diagnosa. Pada FFA dapat mengevaluasi perubahan patologi vaskular termasuk aneurisma, kebocoran kapiler dan area iskemik. Sedangkan Optical Coherence Tomography (OCT) dapat menunjang diagnosa dan evaluasi perubahan patologi retina dengan hipertensi berat. Beberapa perubahan patologi termasuk edem makula, area serous retinal detachment, atau makroaneurisma arteri retina. Informedasi dari OCT melengkapi diagnosis yang didapat dari pemeriksaan klinis dan FFA. ${ }^{15}$

Beberapa klasifikasi pernah dikemukakan para ahli untuk stadium perubahan retina akibat hipertensi. Ada dua klasifikasi yang paling banyak diterima, yaitu klasifikasi Keith-Wagener dan klasifikasi Scheie. Klasifikasi Keith-Wagener masih dianggap klasifikasi yang cukup baik yang merupakan kombinasi temuan klinis dan atherosklerosis. Pertama kali dikemukan pada tahun 1939 dan beberapa modifikasi telah dilakukan diantaranya oleh Scheie tahun 1953 dan Leisman pada tahun $1957^{1,9,11,12}$

\section{Klasifikasi KEITH-WAGENER ${ }^{11}$}

- Grade I :Perubahan retina hanya pada pembuluh darah arteriol berupa penyempitan dan sklerosis. Biasanya pada hipertensi ringan.

- $\quad$ Grade II :Arteriol terlihat lebih sempit dan juga ditemukan adanya penyempitan fokal dan sklerosis, ditandai dengan adanya fenomena arteriolvenous crossing.

- Grade III :Gambaran stadium II ditambah dengan adanya bercak perdarahan dari bentuk dot sampai flame shape, eksudat dan 
perubahan vasospastik, termasuk konstriksi arteriol fokal dan cottonwool spot.

- Grade IV :Gambaran pada stadium III berlanjut dengan adanya edem papil dan pembuluh darahnya terlihat lebih halus.

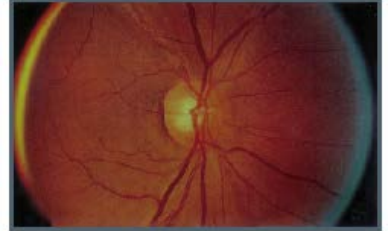

A
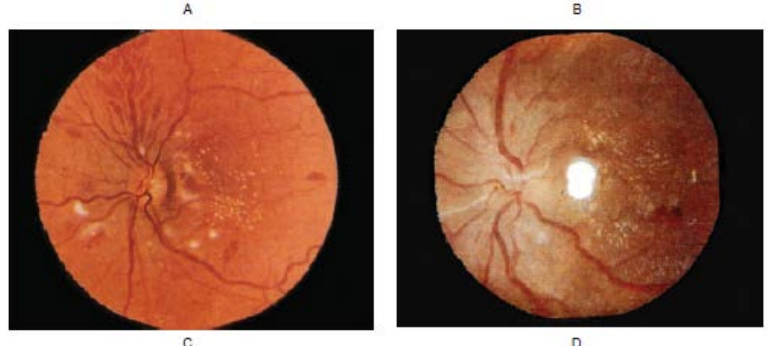

Gambar 1. Retinopati hipertensi menurut Keith Wagener: A. Grade I, B. Grade II, C. Grade III, D. Grade IV. ${ }^{11}$

E. Penatalaksanaan

Data dari studi terbaru mendukung pedoman hipertensi mengenai prognostik yang penting dari tanda retinopati hipertensi. Pedoman ini menekankan bahwa retinopati hipertensi, hipertrofi ventrikel kiri dan gangguan ginjal, dapat dianggap sebagai indikator kerusakan target organ, sehingga dapat menjadi indikasi dalam mempertimbangkan pendekatan yang lebih agresif untuk penatalaksanaan tekanan darah. Adanya tanda retinopati hipertensi merupakan indikasi untuk dimulainya terapi antihipertensi dan dilakukan intervensi lebih agresif untuk mengetahui faktor resiko kardiovaskular dan ko-morbiditas. ${ }^{15}$

Berdasarkan klasifikasi sederhana retinopati hipertensi, dapat disarankan penatalaksanaan perencanaan untuk pasien dengan berbagai stadium retinopati, yang ditunjukkan pada gambar 2 dibawah ini. $^{10}$

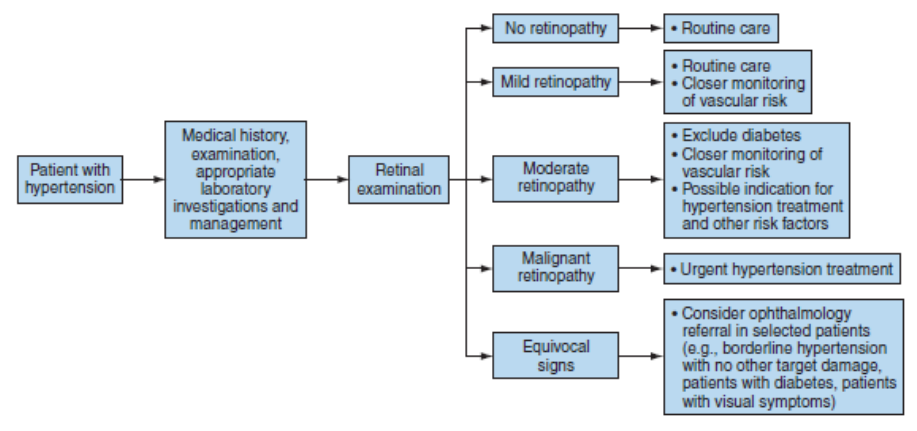

Gambar 2. Evaluasi dan penatalaksanaan pasien dengan retinopati hipertensi ${ }^{10}$

\section{METODE PENELITIAN}

A. Tempat dan Waktu Penelitian

Penelitian dilakukan di poli mata subbagian vitreoretina RSUP. Dr. M. Djamil Padang dari bulan Juli 2012 - September 2012.

B. Disain Penelitian

Penelitian ini merupakan penelitian cross sectional study prospektif. Populasi penelitian adalah pasien yang telah didiagnosis hipertensi oleh bagian penyakit dalam yang berobat ke poli mata subbagian vitreoretina RSUP. Dr. M. Djamil Padang dari bulan Juli 2012 September 2012. Jumlah sampel adalah semua populasi yang diperiksa.

C. Alat dan Bahan

Penelitian menggunakan alat dan bahan sebagai berikut : direct ophthalmoscopy, indirect ophthalmoscopy, Cendo mydriatil 1\% tetes mata, pensil warna, lembaran kuisioner, status pasien, lembaran informeded consent, dan foto fundus.

\section{Definisi Operasional}

- Hipertensi adalah meningkatnya tekanan darah sistolik lebih dari $140 \mathrm{mmHg}$ dan atau diastolik lebih dari $90 \mathrm{mmHg}$. Diagnosis ditegakkan sesuai standar di bagian Penyakit Dalam RSUP DR.M.Djamil Padang

- Retinopati hipertensi adalah keadaan dimana ditemukantanda-tanda perubahan vaskular retina yang secara patologis berhubungan dengan kerusakan mikrovaskular sebagai akibat tekanan darah yang meningkat.

- Klasifikasi Keith Wagener adalah klasifikasi retinopati hipertensi menurut Keith Wagener : 
- Grade I bila perubahan retina hanya berupa penyempitan dan sklerosis arteriol retina.

o Grade II bila arteriol terlihat lebih sempit dan juga ditemukan adanya penyempitan fokal dan sklerosis, ditandai dengan adanya fenomena arteriolvenous crossing.

- Grade III bila gambaran grade II ditambah dengan adanya bercak perdarahan dari bentuk dot sampai flame shape, eksudat dan perubahan vasospastik, termasuk konstriksi arteriol fokal dan cottonwool spot.

- Grade IV bila gambaran pada grade III berlanjut dengan adanya edem papil dan pembuluh darahnya terlihat lebih halus

- Riwayat Diabetes Melitus, jantung, ginjal dan stroke adalah riwayat penyakit sistemik lainnya yang sudah didiagnosis di bagian Penyakit Dalam dan Neurologi sebelumnya dan dapat dilihat pada catatan rekam medis pasien.

- Dislipidema adalah kelainan metabolisme lipid yang ditandai dengan peningkatan dan penurunan fraksi lipid dalam plasma Kelainan fraksi lipidnya adalah kenaikan kadar kolesterol total, kolesterol LDL dan trigliserida serta penurunan kadar kolesterol HDL. Kelainan ini dapat dilihat pada catatan rekam medis pasien.

- Konsumsi alkohol adalah minum minuman yang mengandung alkohol $\pm 500 \mathrm{cc} / \mathrm{hari}$

- Perokok bila diketahui merokok > 6 batang sehari

- Body Mass Index(BMI): $\mathrm{kg} / \mathrm{m}^{2}$

Underweight $(<18,50)$

Normal $(18,50-24,99)$

Overweight $(\geq 25,00)$

Obesitas $(\geq 30,00)$

- Terkontrol : dikatakan Ya bila rutin kontrol hipertensi $1 x$ sebulan ke poli penyakit dalam atau puskesmas atau klinik.
E. Kriteria Sampel

a. Kriteria Inklusi:

o Pasien yang sudah didiagnosis hipertensi dari bagian Penyakit Dalam dan dirujuk ke poli mata subbagian vitreoretina RSUP. Dr. M. Djamil Padang.

o Pasien sudah menyatakan prsetujuan secara tertulis (informed consent) untuk ikut serta dalam penelitian.

b. Kriteria Ekslusi:

o Pasiendengan kelainan media refraksi sehingga tidak bisa diperiksa segmen posteriornya

o Pasien dengan kelainan segmen posterior selain retinopati hipertensi.

F. Cara Kerja

o Informed consent pasien. Diterangkan terlebih dahulu tentang tujuan dan prosedur penelitian kemudian diminta persetujuannya menjadi subjek dalam penelitian ini.

o Dilakukan pengisian kuesioner.

- Dilakukan pemeriksaan oftalmologi secara umum.

o Kedua mata pasien ditetes Cendo mydriatil $1 \%$ tetes

- Dilakukan pemeriksaan segmen posterior dengan direct dan indirect ophthalmoscopy setelah pupil lebar.

o Dilakukan foto fundus pada kedua mata.

O Dilakukan penilaian terhadap hasil pemeriksaan dan klasifikasi Keith Wagener.

\section{HASIL}

Penelitian yang dilakukan mulai bulan Juli September 2012 meliputi 86 pasien hipertensi. Didapat perbandingan pria dan wanita hampir sama. Dari 86 pasien tersebut didapat $70(84,1 \%)$ pasien yang telah mengalami Retinopati Hipertensi. Hasil lebih lanjut dapat dilihat pada tabel-tabel dibawah ini.

Tabel 1. Distribusi subjek penelitian berdasarkan diagnosis menurut Keith Wagener 


\begin{tabular}{|l|c|c|}
\hline \multicolumn{1}{|c|}{ Diagnosa } & $\begin{array}{c}\text { Juml } \\
\text { ah }\end{array}$ & \% \\
\hline $\begin{array}{l}\text { Tidakadatandaretinopatihi } \\
\text { pertensi }\end{array}$ & 16 & $\begin{array}{c}18,6 \\
1\end{array}$ \\
\hline Keith Wagener grade I & 20 & $\begin{array}{c}23,2 \\
6\end{array}$ \\
\hline Keith Wagener grade II & 38 & $\begin{array}{c}44,1 \\
9\end{array}$ \\
\hline Keith Wagener grade III & 12 & $\begin{array}{c}13,9 \\
4\end{array}$ \\
\hline Keith Wagener grade IV & 0 & 0 \\
\hline Total & 86 & 100 \\
\hline
\end{tabular}

Pada tabel 1 memperlihatkan distribusi diagnosis pada subjek penelitian menurut Keith Wagener, dari total pasien 86 orang, paling banyak di diagnosa sebagai Retinopati Hipertensi Keith Wagener grade II yaitu 38 orang (44,19\%), tidak ada yang di diagnosis dengan Retinopati Hipertensi Keith Wagener grade $I V$, dan sebanyak 16 orang $(18,61 \%)$ tidak ada tanda Retinopati Hipertensi.

Tabel 2. Distribusi subjek penelitian berdasarkan jenis kelamin dan kelompok umur dengan diagnosis retinopati hipertensi menurut Keith Wagener

\begin{tabular}{|c|c|c|c|c|c|}
\hline \multirow[t]{2}{*}{ Profil } & \multicolumn{5}{|c|}{ Keith Wagener } \\
\hline & $\begin{array}{l}\text { Grad } \\
\text { e I }\end{array}$ & $\begin{array}{l}\text { Grad } \\
\text { e II }\end{array}$ & $\begin{array}{l}\text { Grad } \\
\text { e III }\end{array}$ & $\begin{array}{l}\text { Grad } \\
\text { e IV }\end{array}$ & Total \\
\hline \multicolumn{6}{|c|}{ JenisKelamin } \\
\hline Pria & 9 & 18 & 8 & 0 & 35 \\
\hline \multirow[t]{2}{*}{ Wanita } & 11 & 20 & 4 & 0 & 35 \\
\hline & & & & & 70 \\
\hline \multicolumn{6}{|c|}{ KelompokUmur } \\
\hline $\begin{array}{l}20-30 \\
\text { tahun }\end{array}$ & 1 & 0 & 0 & 0 & 1 \\
\hline $\begin{array}{l}31-40 \\
\text { tahun }\end{array}$ & 0 & 1 & 1 & 0 & 2 \\
\hline $\begin{array}{l}41-50 \\
\text { tahun }\end{array}$ & 5 & 4 & 1 & 0 & 10 \\
\hline $\begin{array}{l}51-60 \\
\text { tahun }\end{array}$ & 7 & 19 & 5 & 0 & 31 \\
\hline $\begin{array}{l}61-70 \\
\text { tahun }\end{array}$ & 6 & 13 & 3 & 0 & 22 \\
\hline \multirow{2}{*}{$\begin{array}{l}>71 \\
\text { tahun }\end{array}$} & 1 & 1 & 2 & 0 & 7 \\
\hline & & & & & 70 \\
\hline
\end{tabular}

berdasarkan jenis kelamin, sama perbandingan pria dan wanita. Berdasarkan kelompok umur, didapat frekwensi terbanyak pada 51-60 tahun 31 orang, terutama pada Grade /l sebanyak 19 orang.

Tabel 3. Distribusi subjek penelitian berdasarkan riwayat hipertensi dengan diagnosis retinopati hipertensi menurut Keith Wagene

\begin{tabular}{|l|l|l|l|l|l|l|}
\hline Profil & \multicolumn{6}{|c|}{ Keith Wagener } \\
\cline { 2 - 7 } & Tidak & $\begin{array}{l}\text { Grad } \\
\text { e I }\end{array}$ & $\begin{array}{l}\text { Grad } \\
\text { e II }\end{array}$ & $\begin{array}{l}\text { Gra } \\
\text { de III }\end{array}$ & $\begin{array}{l}\text { Gra } \\
\text { de } \\
\text { IV }\end{array}$ & $\begin{array}{l}\text { Tot } \\
\text { al }\end{array}$ \\
\hline \multicolumn{7}{|l|}{ RiwayatHipertensi } \\
\hline $\begin{array}{l}<1 \\
\text { tahun }\end{array}$ & 9 & 11 & 4 & 1 & 0 & 25 \\
\hline $\begin{array}{l}1-2 \\
\text { tahun }\end{array}$ & 2 & 1 & 4 & 2 & 0 & 9 \\
\hline $\begin{array}{l}2-5 \\
\text { tahun }\end{array}$ & 3 & 4 & 8 & 3 & 0 & 18 \\
\hline $\begin{array}{l}5-10 \\
\text { tahun }\end{array}$ & 2 & 3 & 13 & 4 & 0 & 22 \\
\hline $\begin{array}{l}>10 \\
\text { tahun }\end{array}$ & 0 & 1 & 9 & 2 & 0 & 12 \\
\hline & & & & & 86 \\
\hline
\end{tabular}

Berdasarkan riwayat hipertensi terbanyak pada kelompok umur 5-10 tahun 13 orang (18,57\%). Pada riwayat hipertensi $>10$ tahun semuanya menderita retinopati hipertensi.

Tabel 4. Distribusi subjek penelitian berdasarkan riwayat penyakit sistemik lainnya dengan diagnosis retinopati hipertensi menurut Keith Wagener

\begin{tabular}{|l|l|l|l|l|l|}
\hline $\begin{array}{l}\text { Riwayat } \\
\text { penyakit } \\
\text { systemic } \\
\text { lainnya }\end{array}$ & $\begin{array}{l}\text { Grade } \\
\text { I }\end{array}$ & $\begin{array}{l}\text { Grade } \\
\text { II }\end{array}$ & $\begin{array}{l}\text { Grade } \\
\text { III }\end{array}$ & $\begin{array}{l}\text { Grade } \\
\text { IV }\end{array}$ & Total \\
\hline $\begin{array}{l}\text { Diabetes } \\
\text { Melitus }\end{array}$ & 10 & 11 & 3 & 0 & 24 \\
\hline Jantung & 2 & 4 & 2 & 0 & 8 \\
\hline Ginjal & 0 & 0 & 0 & 0 & 0 \\
\hline Stroke & 1 & 1 & 1 & 0 & 3 \\
\hline Lainnya & 2 & 0 & 0 & 0 & 2 \\
\hline Tidak & 10 & 7 & 0 & 0 & 17 \\
ada & & & & & \\
\hline & \multicolumn{7}{|l|}{} \\
\hline
\end{tabular}


Jika berdasarkan penyakit sistemik lainnya, terbanyak pada Retinopati Hipertensi grade II dengan Diabetes Melitus 24 orang (34,29\%). Pada pasien dengan riwayat penyakit sistemik lainnya seperti jantung 8 orang dan stroke (3 orang) semuanya mempunyai kelainan retinopati hipertensi.

Tabel 5. Distribusi subjek penelitian berdasarkan faktor resiko dan $B M I$ dengan diagnosa retinopati hipertensi menurut Keith Wagener

\begin{tabular}{|c|c|c|c|c|c|}
\hline \multirow[t]{2}{*}{ Profil } & \multicolumn{5}{|c|}{ Keith Wagener } \\
\hline & $\begin{array}{l}\text { Grade } \\
\text { I }\end{array}$ & $\begin{array}{l}\text { Grade } \\
\text { II }\end{array}$ & $\begin{array}{l}\text { Gra } \\
\text { de } \\
\text { III }\end{array}$ & $\begin{array}{l}\text { Gra } \\
\text { de } \\
\text { IV }\end{array}$ & $\begin{array}{l}\text { Tot } \\
\text { al }\end{array}$ \\
\hline \multicolumn{6}{|c|}{ Faktor Resiko } \\
\hline Dislipidemia & 14 & 23 & 6 & 0 & 43 \\
\hline Alkohol & 0 & 1 & 0 & 0 & 1 \\
\hline Perokok & 8 & 17 & 5 & 0 & 26 \\
\hline & & & & & 70 \\
\hline \multicolumn{6}{|c|}{ Body Mass Index } \\
\hline $\begin{array}{l}\text { Under } \\
\text { weight }\end{array}$ & 2 & 1 & 1 & 0 & 4 \\
\hline Normal & 9 & 15 & 6 & 0 & 30 \\
\hline $\begin{array}{c}\text { Over } \\
\text { weight }\end{array}$ & 5 & 20 & 5 & 0 & 30 \\
\hline Obesitas & 4 & 2 & 0 & 0 & 6 \\
\hline & & & & & 70 \\
\hline
\end{tabular}

Berdasarkan faktor resiko yang didapat dislipidemia merupakan faktor resiko terbanyak yaitu 43 orang $(61,43 \%)$. Diikuti 26 orang perokok. Distribusi berdasarkan $B M I$ terbanyak didapatkan pada $B M I$ normal (30 orang) dan overweight (30 orang).

Tabel 6. Distribusi subjek penelitian berdasarkan terkontrol hipertensi dengan diagnosis retinopati hipertensi menurut Keith Wagener

\begin{tabular}{|l|l|l|l|l|l|}
\hline \multirow{2}{*}{$\begin{array}{l}\text { Terkon } \\
\text { trol }\end{array}$} & \multicolumn{5}{|c|}{ Keith Wagener } \\
\cline { 2 - 6 } & Grade I & $\begin{array}{l}\text { Grade } \\
\text { II }\end{array}$ & $\begin{array}{l}\text { Grade } \\
\text { III }\end{array}$ & $\begin{array}{l}\text { Grade } \\
\text { IV }\end{array}$ & $\begin{array}{l}\text { To } \\
\text { tal }\end{array}$ \\
\hline Ya & 9 & 26 & 5 & 0 & 40 \\
\hline Tidak & 11 & 12 & 7 & 0 & 30 \\
\hline \multicolumn{7}{|l|}{} \\
\hline
\end{tabular}

Berdasarkan pasien mengontrol penyakit hipertensinya didapat yang rutin 30 orang $(42,86 \%)$.
Pada penelitian yang dilakukan di Poliklinik Mata RSUP Dr.M.Djamil Padang selama periode Juli September 2012 didapat 86 pasien yang datang ke sub bagian vitreo retina dengan diagnosa dari bagian penyakit dalam sebagai hipertensi. Dari 86 pasien tersebut perbandingan pria dan wanita hampir sama yaitu 40 dan 46 orang. Sedangkan jika dilihat dari yang telah didiagnosa sebagai Retinopati Hipertensi perbandingan pria dan wanita seimbang yaitu 35 orang (50\%). Pada penelitian First National Health and Nutrition Examination Survey (NHANES ), pasien yang telah didiagnosa sebagai Retinopati Hipertensi, terdapat perbandingan pria dan wanita adalah 428 (46\%) dan 507 (54\%). ${ }^{14}$ Dari penelitian Gupta et all didapat pria 64 dan wanita 36, didalamnya terdapat pria 47(73\%) dan wanita 22(61,11\%) dengan Retinopati Hipertensi dan pria 17 (27\% dan wanita $(38,89 \%)$ tidak ada tanda retinopati, dari penelitian mereka jenis kelamin tidak berpengaruh besar $(p<0,29) .{ }^{17}$ Sedangkan menurut literatur lain, prevalensi Retinopati Hipertensi lebih tinggi pada wanita daripada pria. $^{17}$

Berdasarkan kelompok umur, pada penelitian ini terbanyak pada rentang umur 51-60 tahun yaitu 31 orang $(44,29 \%)$ dan paling tinggi terdapat pada pasien dengan diagnosis Retinopati Hipertensi Keith Wagener grade II yaitu 19 orang. Pada penelitian yang dilakukan Gupta et all, pada kategori umur 51-60 tahun didapat 33 pasien (33\%) dengan 23 (69,70\%) pasien retinopati dan 10 (30,30\%) tanpa retinopati, mereka menemukan juga bahwa retinopati meningkat nyata pada umur diatas 50 tahun. ${ }^{17}$ Menurut studi epidemiologik, tanda retinopati biasanya timbul pada usia lebih dari 40 tahun, dengan tingkat prevalensi antara 2 - $15 \%$ untuk variasi tanda retinopati. 3,4, 18

Pada penelitian ini, dari 86 pasien, terdapat 70 pasien yang mempunyai tanda Retinopati Hipertensi, frekwensi terbanyak terdapat pada kelompok pasien dengan riwayat hipertensi 5-10 tahun sebanyak 20 orang $(28,57 \%)$, pasien dengan riwayat hipertensi $>10$ tahun 12 orang semuanya terdapat tanda retinopati terbanyak pada variasi grade II pada 9 orang (75\%). Dari penelitian Gupta et all, dari total 100 pasien, ada 47 pasien dengan riwayat hipertensi 0-5 tahun, 18 (38,3\%) retinopati dalam berbagai 
derajat dan $29(61,7 \%)$ tanpa retinopati. Kemudian terdapat 28 pasien dengan riwayat hipertensi 6-10 tahun, didapat $26(92,86 \%)$ retinopati dan 2 (7,14\%) tanpa retinopati, kelompok berikutnya terdapat 18 pasien dengan riwayat hipertensi 10-15 tahun, semuanya terdapat tanda retinopati. ${ }^{15}$ Data dari Beaver Dam Eye Study, suatu studi terhadap 4926 pasien dewasa rentang usia 43-86 tahun di Wisconsin, memperlihatkan bahwa 5 tahun insiden penyempitan arteriolar fokal, AV nicking, perdarahan retinal dan mikroaneurisma pada populasi tanpa diabetes berkisar antara $6-10 \% .^{18}$

Dari penelitian ini, didapat penyakit sistemik lainnya yang diderita oleh pasien selain hipertensi terbanyak adalah Diabetes Melitus yaitu 24 orang $(34,29 \%)$. Berdasarkan distribusi diagnosis menurut Keith Wagenerterutama didapat pada grade I dan II. Kemudian diikuti penyakit jantung 8 orang dan stroke 3 orang. Penelitian Atherosclerosis Risk in Communities (ARIC) Study terdapat hubungan kuat antara Retinopati Hipertensi dengan diabetes, sesuai dengan mikroaneurisma, perdarahan retina, dan soft exudate yang biasa terlihat ketika rusaknya blood retinal barrier. ${ }^{4}$ Pada penelitian populasi selama 3 tahun tersebut berdasarkan cohort study terhadap resiko aterosklerosis, didapat insiden stroke meningkat pada pasien dengan Retinopati Hipertensi daripada pasien tanpa retinopati. Pada analisa studi tersebut, kontrol pada tekanan darah, diabetes, lipid, dan faktor resiko lainnya, tanda Retinopati Hipertensi sedang menjadi 2 - 4 kali lipat resiko tinggi terjadinya insiden stroke. ${ }^{3}$ Penelitian terakhir dari Atherosclerosis Risk in Communities (ARIC) Study mendapatkan bahwa tanda dari mikrovaskular retina dapat menjadi tanda untuk prognostik kemungkinan stroke dan penyakit jantung koroner dan diabetes. ${ }^{19}$ Pada National Health Examination Survey didapatkan bila ada penyempitan arteriolar retina yang ditemukan pada funduskopi, 2-6 kali dapat menjadi pencetus penyakit jantung koroner , setelah analisa terhadap kontrol ada atau tidaknya hipertensi, diabetes dan tingkat kolesterol serum. ${ }^{3}$

Sedangkan faktor resiko lainnya, selain penyakit sistemik, pada penelitian ini terbanyak didapat adalah dislipidemia pada 43 orang (61,43\%) terutama terdapat pada Retinopati Hipertensi Keith
Wagener grade /I yaitu 23 orang, kemudian diikuti perokok 33 orang $(34,37 \%)$ dan alkohol 1 orang $(1,43 \%)$. Pada beberapa penelitian terdapat peningkatan insiden Retinopati Hipertensi pada peningkatan kolesterol total serum LDL serum, dan trigliserida serum. Tapi tidak terdapat korelasi antara HDL serum dengan Retinopati Hipertensi. Salah satu penelitiannya yang dilakukan oleh Gupta et all dan Bastola et all.444,15,19 Pada penelitian Wang et all terdapat hubungan yang signifikan antara hipertensi dan insiden retinopati dengan konsumsi alkohol. ${ }^{18}$

Pada penelitian ini, distribusi diagnosa pada subjek penelitian menurut KeithWagener, dari total pasien 86 orang, paling banyak di diagnosis sebagai Retinopati Hipertensi Keith Wagener grade II yaitu 38 orang (44,19\%), tidak ada yang di diagnosa dengan Retinopati hipertensi Keith Wagener grade IV, dan sebanyak 16 orang (18,61\%) tidak ada tanda Retinopati Hipertensi. Pada penelitian oleh Choi Young di Mulago Hospital, pada Maret-Mei 2005 (3 bulan) terhadap 161 pasien, didapat 113 (70,2\%) dengan retinopati hipertensi, terbanyak adalah Retinopati Hipertensi Keith Wagener grade I 57,35\%. ${ }^{15}$ Pada penelitian Figueiredo Neto et all, ada 99 pasien yang dievaluasi, didapatkan bila pemeriksaan dengan menggunakan oftalmoskop, terbanyak Retinopati Hipertensi Keith Wagener grade I (51,0\%) dan grade II (43,0\%). Tapi bila pemeriksaan menggunakan angiografi didapatkan grade I (42,0\%) dan grade II (52,0\%). ${ }^{19}$ Pada penelitian Wang et all pada Beijing Eye Study di Beijing China pada tahun 2001 yang kemudian di follow up th 2006, didapat dari 2508 pasien, insiden 5 tahun terhadap focal narrowing ( $F N$ ), arteriovenous nicking ( $A V N$ ) dan retinopati adalah $4,1 \%, 1,1 \%$, dan 3,3\%. Insiden 5 tahun FN, AVN dan retinopati tidak berbeda secara signifikan berdasarkan usia dan jenis kelamin. Dengan analisa univariat, insiden 5 tahun FN, AVN dan retinopati lebih tinggi secara signifikan pada kelompok pasien hipertensi daripada pasien normotensi. Setelah penyesuaian terhadap umur, jenis kelamin dan regio tempat tinggal, insiden 5 tahun $\mathrm{FN}, \mathrm{AVN}$ dan retinopati meningkat untuk setiap peningkatan $10 \mathrm{mmHg}$ tekanan darah arterial rata-rata dan insidennya meningkat 1,52 kali. ${ }^{15,20}$ 
Berdasarkan Body Mass Index (BMI), pada penelitian ini distribusi terbanyak sama pada $B M I$ normal yaitu 30 orang dan BMI overweight 30 orang $(42,86 \%)$. Menurut penelitian Wang et all, insiden abnormalitas mikrovaskular retina tidak berhubungan signifikan dengan hiperlipidemia, riwayat sakit jantung dan stroke serta BMI. ${ }^{22}$ Studi yang dilakukan oleh Suri dan Qureshi, mengatakan bahwa setelah penyesuaian untuk umur, jenis kelamin, ras, BMI, merokok, tekanan darah sistolik, kolesterol, dan diabetes melitus dengan Retinopati Hipertensi didapatkan ada resiko relatif 1,2 (95\% confidence interval 1,0-1,3) untuk penyakit kardiovaskuler dan resiko relatif 1,2 (95\% confidence interval 0,9-1,5) untuk stroke iskemik. ${ }^{16}$

Pada penelitian ini berdasarkan kontrol hipertensi ke bagian Penyakit Dalam, puskesmas atau klinik didapat perbandingan pasien yang rutin kontrol dengan tidak, tidak signifikan yaitu $31,43 \%$ dan $42,86 \%$. Wang et all mendapatkan insiden retinopati meningkat 2,34 dan 3,29 kali pada grup terapi hipertensi tidak terkontrol dan grup hipertensi tidak diterapi. ${ }^{18}$

Pada penelitian di Beijing Eye Study ini, tingkat regresi FN paling tinggi pada pasien hipertensi terkontrol tekanan darahnya dengan terapi, tapi terendah pada pasien hipertensi tanpa terapi. Tingkat regresi $\mathrm{FN}$ menurun $28 \%$ pada setiap peningkatan stadium dari klasifikasi hipertensi. Sedangkan AVN yang menunjukkan regresi $1,7 \%$ pada pemeriksaan follow up 5 tahun berikutnya. Disimpulkan pada penelitian tersebut, FN mewakili fenomena mirip dengan arteriospasme, yang menjelaskan proses patologi retinopati hipertensi pada stadium awal. Jika hipertensi terkontrol, FN akan regresi, menunjukkan dapat reversibel, lebih fungsional dan berubah. Jika hipertensi tidak diterapi dalam periode 5 tahun, terjadi perubahan struktur vaskular dalam bentuk AVN yang hanya sedikit bisa regresi, sehingga menunjukkan perubahan struktur yang ireversibel. Sesuai dengan studi sebelumnya bahwa AVN tidak hanya berhubungan dengan tekanan darah saat itu tapi juga pada periode 6-8 tahun sebelumnya, mencerminkan kerusakan kronis pada pembuluh darah. ${ }^{6,15}$

\section{KESIMPULAN}

1. Pada penelitian ini dari 86 pasien dengan diagnosa hipertensi didapat $70(81,4 \%)$ orang yang ada Retinopati Hipertensi, dengan distribusi terbanyak pada Retinopati Hipertensi Keith Wagener grade II 44,19\%, tidak dijumpai Retinopati Hipertensi Keith Wagener IV, dan masih ditemukan penderita hipertensi yang tidak menderita retinopati walaupun sudah diketahui menderita hipertensi lebih dari 5 tahun.

2. Penderita retinopati hipertensi sama antara pria dan wanita, dengan kelompok umur terbanyak terdapat pada rentang umur 51-60 tahun.

3. Pada 70 pasien yang mempunyai tanda Retinopati Hipertensi, frekwensi terbanyak terdapat pada kelompok pasien dengan riwayat hipertensi 5-10 tahun, pasien dengan riwayat hipertensi >10 tahun semuanya mempunyai tanda retinopati.

4. Penyakit sistemik lainnya yang diderita oleh pasien selain hipertensi terbanyak adalah Diabetes Melitus. Diikuti penyakit jantung dan stroke yang semuanya sudah mendapat tanda retinopati hipertensi

5. Faktor resiko lainnya, selain penyakit sistemik, pada penelitian ini terbanyak pada dislipidemia kemudian diikuti perokok.

6. Berdasarkan Body Mass Index (BMI), distribusi hampir sama pada BMI normal dan overweight.

\section{DAFTAR PUSTAKA}

1. Murphy RB, Lam LA, Chew EY. Hypertension. In: Retina. $4^{\text {th }}$ Edition. Philadelphia: Elsevier Mosby. (2006). 13771381.

2. Khatib O, El-Guindy MS. Clinical Guidelines for the Management of Hypertension. WHO Regional Office for the Eastern Mediterranean Cairo. (2005). 27-9.

3. Wong TY, Mitchell P. Current Concepts Hypertensive Retinopathy. New England J Med (2004). 351, 2310-17.

4. Grosso A, Veglio F, Porta M, Grignolo FM, Wong TY. Hypertensive Retinopathy Revisited: Some Answers, More Questions. $\mathrm{Br} \mathrm{J}$ Ophthalmol (2005) 89, 1646-54.

5. Wong $T$, Mitchell $P$. The Eye in Hypertension. Lancet (2007) 369: 425-35.

6. Erden S, Bicakci E. Hypertensive Retinopathy: Risk Factors, and Comorbidities. Clinical and Experimental Hypertension. 2012; 34(6): 397-401. 
7. Quillen DA, Blodi BA. Retinal Vascular Diseases. In : Clinical Retina. American Medical Association.(2002).136-137.

8. Lang G. Retina. In : Ophthalmogy A Pocket Texbook Atlas. Thieme. (2007) 2. 333-335.

9. Wolf S, Klesert T, Schachat AP. Hypertensive Retinopathies. In : Retinal Vascular Disease. Springer.(2007). 688-699.

10. Rogers $\mathrm{AH}$. Hypertensive Retinopathy. In : Ophthalmology ,3 rd.. 584-588.

11. Kanski JJ. Retinal Vascular Disease. In: Clinical Ophthalmology a Systematic Approach. Philadelphia: Elsevier ButterworthHeinemann. 2007: 598-601.

12. Khurana AK. Diseases of the Retina. In: Comprehensive Ophthalmology. New Delhi: New Age International.( 2007 ): 249-252.

13. Skuta GL, Cantor BL, Weis JS. Retinal Vascular Disease.In: Retina and Vitreous. American Academy of Ophthalmology. San Fransisco. (2011): 107-109.

14. Hao Chen, Kung Kuo, Lun Kao. Malignant Hypertensive Retinopathy-Clinical and Fundus Manifestations in Patients with New Onset or Acute Exacerbation of Chronic Hypertension. Chang Gung Med J.(2003) 26. 669-76.

15. Choi, Youngdan. The Incidence and Associated Factors of Hypertensive Retinopathy Among Hypertensive Patients Attending Mulago Hospital.2005.(diunduh 3 juli 2013). Diakses dari ; http://hdl.handle.net/10570/1593.

16. Suri M, Qureshi A. Hypertensive Retinopathy and Risk of Cardiovascular Diseases in a Natinal Cohort. Journal of Vascular and Interventional Neurology. (2008) 1. 75-8.

17. Gupta R, Gupta Sonal, Sukharamwala D, Gahlot Abha. Evaluation of Hypertensive Retinopathy in Patients of Essensial Hypertension with High Serum Lipids. Medical Journal of Dr.D.Y.Patil University. (2013) 6.165-169.

18. Wang Shuang, . Five Year Incidence of Retinal Microvascular Abnormalities and Assocoations with Arterial Hypertension: The Beijing Eye Study 2001/2006. American Academy of Ophthalmology. Elsevier Inc. (2012) : 2592-2598.

19. Wong TY, Mcintosh $R$ Hypertensive Retinopathy Signs as Risk Indicators of Cardiovascular Morbidity and Mortality. British Med Bulletin (2005) 73 : 57-70.

20. Wang JJ, Mitchell $P$, Leung $H$, Rochtchina E, Wong TY, Klein R. Hypertensive Retinal Vessel Wall Signs in a General Older Population The Blue Mountain Eye Study. In : Hypertension. American Heart Association (2003) 42. 534-41. 